Seminário de Pesquisa

Programa de Pós-Graduação

Design FAU USP

\title{
Abordagem metodológica centrada no usuário para reconhecimento de parâmetros de design para planejamento de embalagens reutilizáveis em âmbito doméstico
}

\author{
Caio Dutra Profirio de Souza, Cyntia Santos Malaguti de Souza
}

\author{
design de embalagem; design para reúso; design centrado \\ no usuário; cultura e consumo
}

A pesquisa explora a experiência de indivíduos que já tenham implementado novos usos para embalagens (tais como caixas, frascos e potes) em suas residências, após a retirada ou o consumo do produto adquirido, com foco nas instâncias em que tal prática é uma opção do usuário, não um ato de necessidade decorrente de privações socioeconômicas. Lida-se, portanto, com a questão

Curso

Mestrado

\section{Linha de Pesquisa \\ Design: Processos e Linguagens}

Caio Dutra Profirio de Souza Mestrando em Design pela Universidade de São Paulo (USP), possui especialização em Cultura Material e Consumo pela mesma instituição. Tem experiência em Design Gráfico, com interesse de pesquisa em: aspectos sociais e culturais do design; design centrado no usuário; design de embalagens sustentáveis e-mail: caiodutra@usp.br Lattes: http://lattes.cnpq. br/8044564847355346 Orcid: https://orcid.org/00000002-9558-4058

Cyntia Santos Malaguti de Souza Professora Doutora nos cursos de Design da Universidade de São Paulo (graduação e pósgraduação). Tem experiência profissional na área de Desenho Industrial, com pesquisas nos seguintes temas: design para sustentabilidade, gestão do design e cultura material.

e-mail: cyntiamalaguti@usp.br

Lattes: http://lattes.cnpq. br/2565400330040398

Orcid: https://orcid.org/00000001-6339-587X do porquê que as pessoas, apesar de poderem comprar objetos específicos para as suas necessidades domésticas, optam por reaproveitar algumas embalagens. Objetiva-se depreender motivações e situações que desencadeiam o fenômeno, de modo a sistematizar parâmetros de design para o planejamento de embalagens reutilizáveis em âmbito doméstico. Para tanto, adota-se a estratégia explanatória sequencial, método misto caracterizado pela coleta e análise de dados em duas fases, uma quantitativa e outra qualitativa, sendo que os resultados da primeira são usados para desenvolver os procedimentos da seguinte (CRESWELL; CRESWELL, 2018). Deste modo, elaborou-se um questionário virtual visando ao reconhecimento de perfis de indivíduos para o estágio qualitativo, em que se planeja a aplicação de sondas culturais, técnica centrada no usuário que engloba um conjunto de atividades (fotografar, escrever e desenhar, entre outros) propostas aos participantes para que documentem as suas experiências com o objeto de pesquisa (BOEIJEN et al., 2014; MATTELMÄKI, 2003). O material registrado é enviado ao pesquisador para interpretações, as quais serão consolidadas em entrevistas em profundidade semi estruturadas direcionadas aos participantes das sondas. As duas técnicas qualitativas, em fase de elaboração, serão conduzidas de modo virtual. Por fim, será realizada a triangulação dos dados para a comunicação dos resultados. 


\title{
User-centered methodological approach to identify design guidelines for the development of packaging for domestic reuse
}

\author{
Caio Dutra Profirio de Souza, Cyntia Santos Malaguti de Souza
}

\author{
packaging design; designing for reuse; user-centered design; culture \\ and consumption
}

This study explores the experience of individuals who have eventually found new ways of using packaging (such as boxes, bottles and jars) in their homes, after the withdrawal or consumption of the purchased product, focusing on the instances where the reuse is an option of the consumer, not an act of any socioeconomic deprivation. Therefore, the research addresses the question of why people, despite being able to buy specific objects for each of their domestic needs, choose to reuse some packaging. The purpose is to elucidate underlying motivations and situations related to the practice, in order to systematize any guidelines that may contribute to design packaging for domestic reuse. The research follows the explanatory sequential mixed methods approach, a two-phase design in which quantitative data is obtained in the first stage and the results are used to plan the second, qualitative phase, one database helping to explain the other in more detail (CRESWELL; CRESWELL, 2018). Thereby, web survey data was collected to inform the types of participants to be purposefully selected for the qualitative follow-up stage, which involves cultural probes, an user-centered strategy that consists of a collection of tasks (often including taking pictures, writing and drawing) given to participants to self-document their experiences related to the problem (BOEIJEN et al., 2014; MATTELMÄKI, 2003); the collected material returns to researchers for initial interpretations, further complemented and deepened in semi-structured interviews with the probe's participants. Both qualitative techniques are in process of development and will be conducted online. Final discussions merging quantitative and qualitative databases will provide a more complete understanding of the results.

\section{Referências | References}

BOEIJEN, A.; DAALHUIZEN, J.; ZIJLSTRA, J. \& SCHOOR, R. 2014. Delft design guide: design strategies and methods. Amsterdam: BIS.

CRESWELL, J. W. \& CRESWELL, J. D. 2018. Research design: qualitative, quantitative, and mixed methods approaches. Los Angeles: Sage.

MATTELMÄKI, T. 2003. Probes: Studying experiences for design empathy. In: KOSKINEN, I.; BATTARBEE, K. \& MATTELMÄKI, T. (eds.). Empathic design: 119-130. Helsinki: IT Press. management and material culture. e-mail: cyntiamalaguti@usp.br Lattes: http://lattes.cnpq. $\mathrm{br} / 2565400330040398$ Orcid: https://orcid.org/00000001-6339-587X 